\title{
Patterns of larval food production by hypopharyngeal glands in adult worker honey bees
}

\author{
D Knecht, HH Kaatz \\ Lehrstuhl Entwicklungsphysiologie, Zoologisches Institut der Universität Tübingen, \\ Auf der Morgenstelle 28, D-7400 Tübingen, FRG
}

(Received 30 May 1990; accepted 15 June 1990)

\begin{abstract}
Summary - Ultrastructural changes of the hypopharyngeal gland cells were analyzed during imaginal development of worker honey bees (Apis mellifera $L$ ). The rough endoplasmic reticulum increases immediately after emergence, reaches a maximum during the nursing phase and decreases in field bees. Accordingly, high rates of protein synthesis were measured in nurse bees and low protein production in foragers. Secretion reservoirs are formed within the intracellular ductules. They are surrounded by a sheath of numerous microvilli. Larval food proteins are secreted into the reservoirs and stored as demonstrated immunocytochemically. Even in foraging bees, small amounts of larval food proteins are stored, indicating the flexibility of the worker to potentially react to changing colonial and environmental conditions.
\end{abstract}

Apis mellifera / hypopharyngeal gland / protein synthesis / ultrastructure / immunocytochemistry / ontogenesis

\section{INTRODUCTION}

The basic studies of Anna Maurizio pointed to the significance of regular pollen supply for maximum morphogenesis and function of the hypopharyngeal glands in queenright worker honey bees. She demonstrated that pollen not only promotes the initial growth of the glands in adult bees but also promotes the maximum production of honey processing enzymes (Maurizio 1954, 1959, 1961, 1962a). A lack of pollen in the young bee's diet delays the normal functions of the glands. If, later on, a worker is fed on pollen, the glands are capable of growing completely and develop regular functions (Maurizio, 1962b), attaining a normal size in the nurse phase during which mainly larval food proteins are produced (Halberstadt, 1980; Takenaka and Kaatz, 1987). When the workers become foragers, the glands decrease considerably in volume and instead secrete enzymes like invertase (Simpson et al, 1968; Halberstadt, 1980). The functional and morphological transition from nursing to foraging bee is controlled by juvenile hormone (Jaycox, 1976; Robinson, 1987).

Despite a number of ultrastructural studies (Beams et al, 1959; Cruz-Landim and Hadek, 1969; Halberstadt, 1970), functional aspects of the glandular structures have rarely been investigated. Thus, it is 
unknown as to where larval food proteins and secretory enzymes are synthesized and stored and if changes related to age and function occur. Therefore, we analyzed these questions in the course of the lifespan of adult worker bees.

\section{MATERIALS AND METHODS}

The experiments were carried out from May through August 1989 using Carniolan hybrids (Apis mellifera L) from our apiary. Newly emerged workers were colour-marked and kept in queenright colonies until the experiment.

\section{Electron microscopy}

The hypopharyngeal glands were fixed in glutaraldehyde $(3 \%, \mathrm{v} / \mathrm{v}), 0.125 \mathrm{~mol}^{-1} \mathrm{CaCl}_{2}, 0.18$ mol. $\left.\right|^{-1} \mathrm{MgSO}_{4}, 0.064 \mathrm{~mol}^{-1} \mathrm{I}^{-1} \mathrm{~s}$-collidine (stem solution: 0.4 molol-1 s-collidine: $5.34 \mathrm{ml} \mathrm{s}-$ collidine, $18 \mathrm{ml}\left(1 \mathrm{~mol}^{-1}\right) \mathrm{HCl}$ per $\left.100 \mathrm{ml}\right)$ for $2 \mathrm{~h}$ at $4^{\circ} \mathrm{C}$, washed in distilled water and postfixed in osmiumtetroxide $(3.3 \%, w / v)$. They were dehydrated in ethanol and exposed to propyleneoxide which was slowly replaced by Epon resin solution (32 g Epon 812, $16.032 \mathrm{~g} \mathrm{2-}$ dodecenyl succinic acid anhydride, $17.36 \mathrm{~g}$ me-

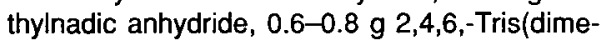
thyl-amino-methyl)phenol). Polymerization lasted $2 \mathrm{~d}$ at $60^{\circ} \mathrm{C}$. Uranylacetate and lead citrate stained ultrathin sections were studied using a Zeiss EM 9.

\section{Antiserum specificity for larval food proteins}

The antiserum was raised in rabbits injected with royal jelly $(0.2 \mathrm{ml})$ and Freund's complete adjuvant. After separation by SDSpolyacrylamide gel electrophoresis on gradient slab gels of 5-20\% acrylamide (Laemmli, 1970), specificity was analyzed by immunoblotting (Towbin et al, 1979) using homogenates of fat body and labial glands (for control purposes), as well as homogenates of hypopharyngeal glands and worker jelly of 1-2-d-old larvae as test samples. The nitrocellulose sheets were incubated with a quenching solution ( $3 \%$ bovine serum albumin in $10 \mathrm{mmol}^{-1}$ tris buffered saline) for $1 \mathrm{~h}$ at $37^{\circ} \mathrm{C}$. Diluted antiserum $(1: 3000)$ was applied overnight at $4^{\circ} \mathrm{C}$, followed by the peroxidase conjugated antiserum against rabbit immunoglobulin $G(1: 2000,2 \mathrm{~h})$. Finally the sheets were stained in 4-chloronaphtol $(0.04 \% \mathrm{w} / \mathrm{v}$, $13.3 \%$ ethanol, $67 \mathrm{mmol} \cdot \mathrm{l}^{-1}$ Tris- $\mathrm{HCl}, 0.015 \%$ $\mathrm{H}_{2} \mathrm{O}_{2}$ ) for 20-30 min at room temperature.

\section{Immunocytochemistry}

The hypopharyngeal glands were fixed in Bouin's solution for $24 \mathrm{~h}$ at $4^{\circ} \mathrm{C}$, dehydrated in ethanol and embedded in glycol methacrylate resin (HistoresinTM, LKB). Sections $(1.5 \mu \mathrm{m})$ were cut with a microtome 1140/Autocut (Jung, Heidelberg), air-dried, mounted on microscopic slides and stained with the PAP method (Sternberger, 1979). Larval food proteins were detected with the antiserum against royal jelly diluted $1: 500$ and incubated for $24 \mathrm{~h}$ at room temperature. The second antibody (1:100 dilution) and the third, peroxidase conjugated antibody $(1: 200)$, were each incubated at $37^{\circ} \mathrm{C}$ for $1 \mathrm{~h}$. Larval food proteins were rendered visible with a 4-chloro-1-naphthol-solution $10.03 \%$ (w/v) dissolved in ethanol (final concentration: $1 \%$ ), $0.03 \%$ $\mathrm{H}_{2} \mathrm{O}_{2}$ in 50 mmol. $\mathrm{I}^{-1}$ Tris buffered saline, $\mathrm{pH}$ 7.6) for $20 \mathrm{~min}$.

\section{Protein synthesis}

Synthesis of water-soluble proteins in the hypopharyngeal glands was determined by an injection of $74 \mathrm{kBq}{ }^{35} \mathrm{~S}$-methionine/2 $\mu$ l into the hemocoel of 10 workers per age group with 2 replicates. The $\mathbf{4 5} \mathrm{min}$ of incubation proved to be linear for tracer incorporation. The dissected glands were homogenized in phosphate buffered saline $\left(150 \mathrm{mmol}^{-1} \mathrm{NaCl}, 40 \mathrm{mmol} \cdot \mathrm{I}^{-1}\right.$ phosphate, $10 \mathrm{mmol}^{-1}$ methionine, $\mathrm{pH} 6.70$ ), centrifuged (10 min, $10000 \mathrm{~g}$ ) and the tracer incorporation into proteins of the supernatant was measured according to Kaatz et al (1985). 


\section{RESULTS}

\section{Rough endoplasmatic reticulum and protein synthesis}

In the pharate adult worker the rough endoplasmatic reticulum (RER) of hypopharyngeal gland cells is scarcely developed and spheroidally arranged (fig 1a). During the first few days after emergence the RER increases rapidly (fig $1 b$ ) until at $d 8$ most of the space between the secretion reservoirs is filled by well-developed lamellar stacks of RER (fig 1c). In foragers the RER decreases and only parts remain (fig 1d). This pattern of ultrastructural development corresponds well to the total protein synthesis monitored in the hypopharyngeal glands in vivo (fig 2). Until d 4 after emergence protein synthesis increases more than 20-fold. During the nursing phase, especially from 8-16 d of age, the highest rates of protein synthesis are observed in the hypopharyngeal glands. After d 20, protein synthesis declines drastically by more than $90 \%$ within $4 d$ and remains at a low level in field bees.

\section{Secretion storage and transport apparatus}

Each gland cell is equipped with a twisted exporting ductule called an intracellular ductule (fig $5 b_{c}$ ). However, a cell membrane separates the ductule from gland cell cytoplasm, indicating extracellular rather than intracellular structures. In addition, the gland cell membrane is folded to a great extent and surrounds the ductule with a sheath of numerous microvilli (fig $3 a-c)$. The ductule is lined by a cuticle which consists of a thin and fenestrated epicuticle and a more extensive, fibrillar endocuticle. Secreted material is found in secretion reservoirs which are formed in the space between the gland cell membrane and endocuticle of the exporting ductule (fig 3b). Thus, the secretion reservoir and the exporting ductule represent a morphological unit providing storage and transport of the secretions.

During adult development, the glandular ultrastructure changes in a typical way. The ductule and the microvilli persist throughout a worker's life, whereas the volume of the secretion reservoirs changes. In the pharate adult worker, the latter is limited to a small space between the endocuticle and gland cell membrane and is still free of any secretions (fig 3a). During the following days the space is filled up with secretional products, reaching a maximum at $\mathbf{d} 8$ (fig $3 \mathrm{~b}$ ). This level persists throughout the hive bee period. Later on, in the field bee stage, the reservoirs shrink gradually until only a small space is left. However, in most foragers examined, the exporting ductules are still filled with secretions (fig 3c). Obviously these changes in the volume of the secretion reservoirs are the prime cause for the volume alterations of the whole glands.

\section{Localization of larval food proteins}

The antiserum raised against royal jelly proteins specifically recognizes all the polypeptides in worker jelly as well as the corresponding secretory proteins within the hypopharyngeal glands. In control tissues no reacting antigens could be detected (fig 4), confirming the specificity of the antiserum.

Using this antiserum for immunocytochemical staining within the hypopharyngeal gland cells, the secretion reservoirs and also the exporting ducts are clearly marked (fig 5a-c). For the first time, the storage of larval food proteins is evidenced 

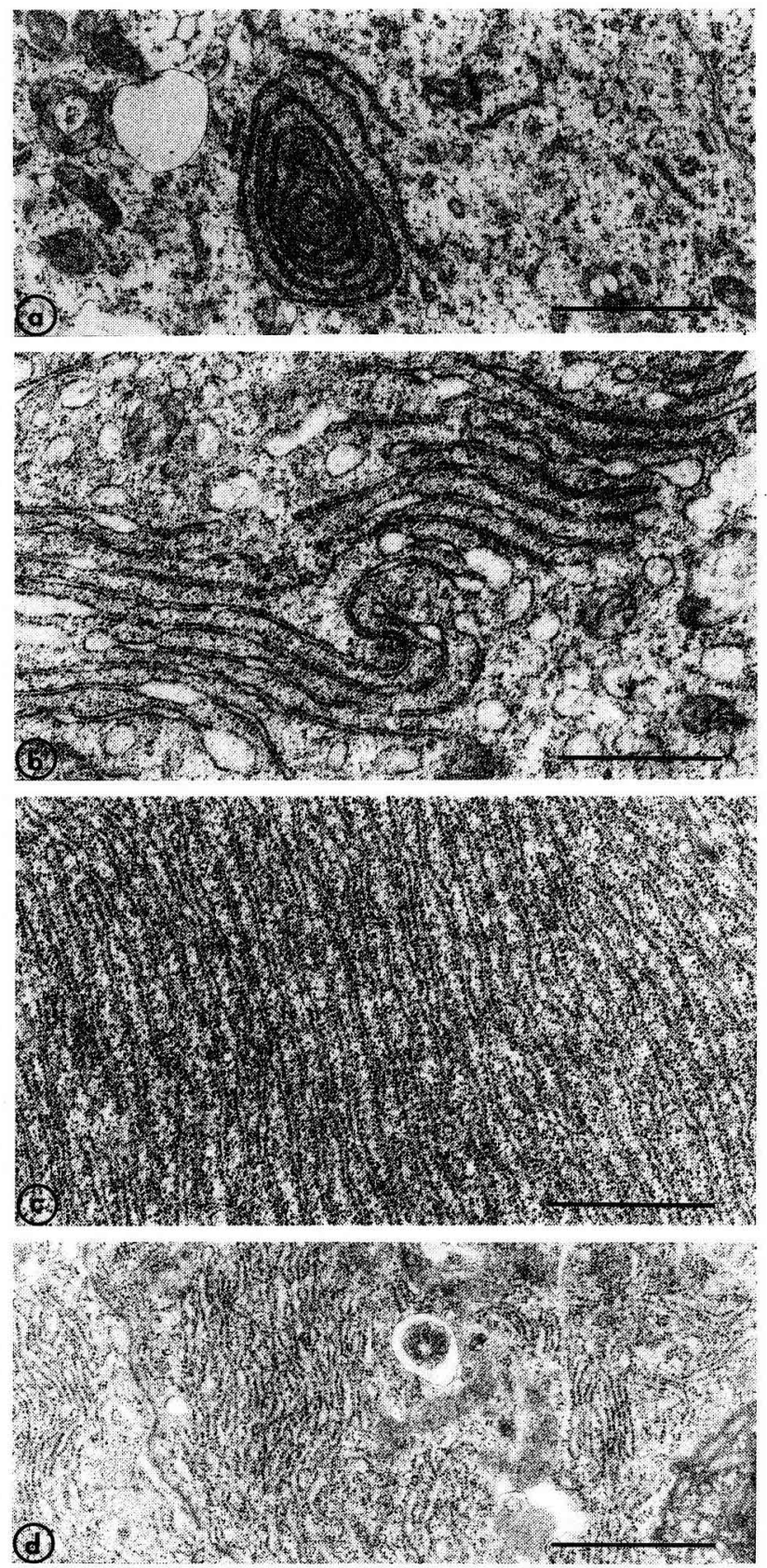

Fig 1. Rough endoplasmic reticulum in hypopharyngeal gland cells, changes in course of imaginal worker development. a) pharate adult, $12 \mathrm{~h}$ before eclosion, b) $2 \mathrm{~d}$ c) $8 \mathrm{~d}$ nurse bee, d) $29 \mathrm{~d}$ forager (bars $=1 \mu \mathrm{m})$. 


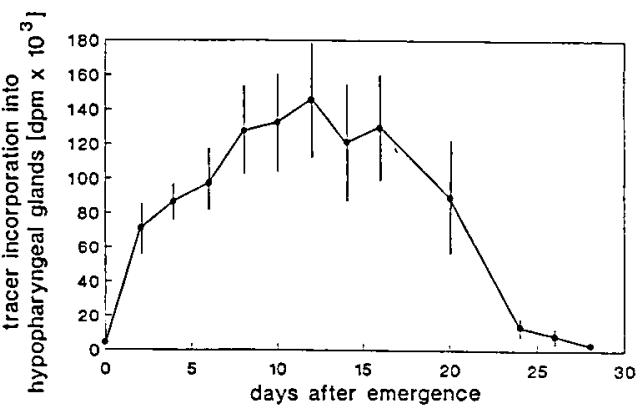

Fig 2. Age-dependent pattern of total protein synthesis in the hypopharyngeal glands. Means of 10-20 pairs of glands, bars: standard error.

within the secretion reservoirs. Since the same picture was obtained in all the acini of any nurse bees examined, it is apparent that no specialization in synthesis and storage exists. Moreover, the intensity of the stain changes in relation to a worker's age. No stain is visible in glandular sections of newly eclosed workers (data not shown). However in newly emerged workers, a weak signal occurs within the exporting ducts and the small secretion reservoirs (fig $5 \mathrm{a}$ ). The intensity of the stain reaches its maximum at $d 8$ (fig 5b). Secretion reservoirs have increased in size and are strongly marked. Surprisingly, the hypopharyngeal glands of foraging bees contain small amounts of larval food proteins (fig 5c). Obviously, the glands contain larval food proteins throughout the lifespan of imaginal bees in varying quantities.

\section{DISCUSSION}

The terms intracellular ductule, extracellular duct, and collecting duct have been used for the 3 exporting structures of the hypopharyngeal glands (Soudek, 1927; Kratky, 1931; Beams et al, 1959; Halber- stadt, 1970). The intracellular ductule has heretofore been regarded as an integral part of each gland cell and as separate from the secretion reservoir. We suggest that the secretion reservoir and the exporting ductule form a functional unit for storage and transport of the secretion material. This unit is separated from the gland cell by a cell membrane. Therefore the term intracellular ductule appears to be misleading. The secretion reservoirs are extensions of the space between the endocuticle and gland cell membrane. They are surrounded by a sheath of microvilli probably involved in exocytosis of the gland cell secretions. Thus, storage of larval food proteins in the secretion reservoirs is combined with the export of the secretions across the fibrillar endocuticle and the fenestrated epicuticle along the ductule.

The secretory cells of the hypopharyngeal gland are equipped with a well developed rough endoplasmatic reticulum (RER), typical of protein-secreting cells. The degree of development of RER in the gland cells (fig 1) as well as the temporal pattern of total protein synthesis (fig 2) match the 3 known phases of glandular size development (Hassanein, 1952; Maurizio, 1954). Gland activity is still low in newly emerged bees, which have rather small glands containing as yet little RER. Within the first days following emergence, as the glands grow and the RER increases, total protein synthesis rises rapidly, continuing until full size and RER development are reached, thus providing high synthetic activity for brood rearing in the nursing phase. After bees become foragers, this protein production declines rapidly. Obviously, the extent of the RER is correlated with the rate of protein synthesis in the hive bee period of imaginal worker development.

We have shown that the secretion reservoirs of summer bees do indeed store 


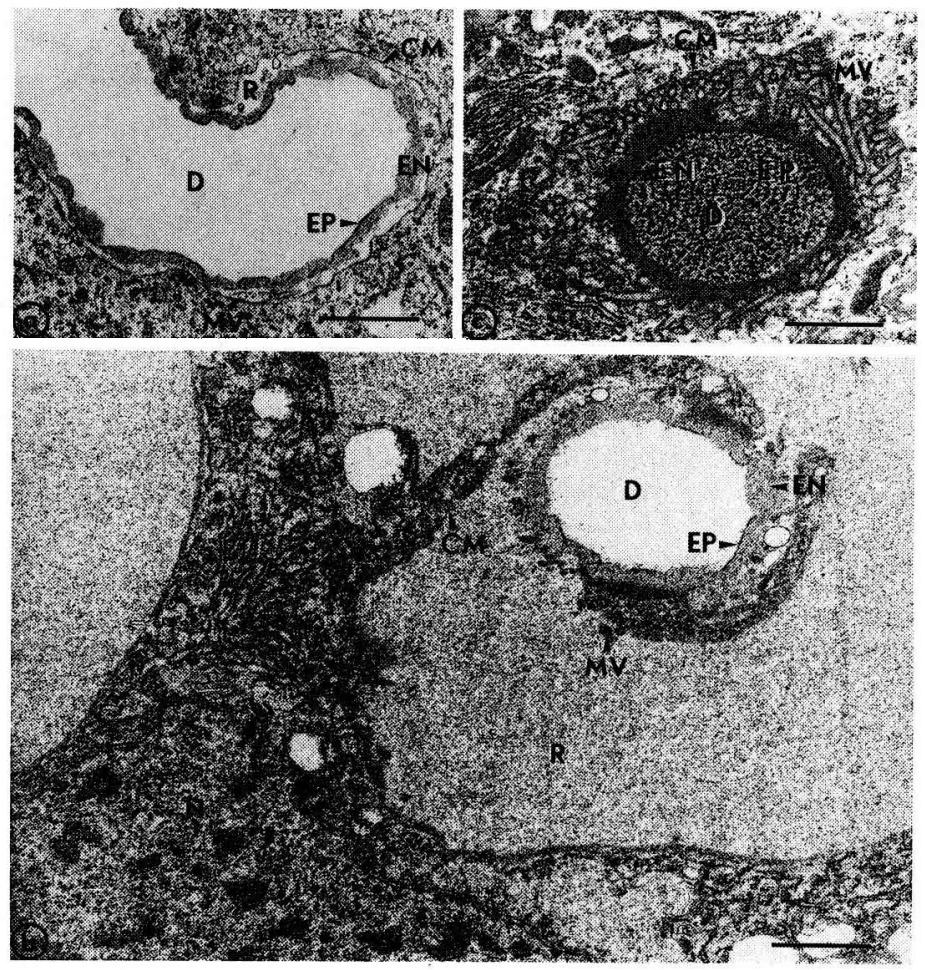

Fig 3. Storage and secretion of proteinaceous products of the hypopharyngeal gland cells in worker bees of different ages. (a) $12 \mathrm{~h}$ before eclosion: empty ductule, (b) $8 \mathrm{~d}$ : empty ductule but densely packed and enlarged secretion reservoir around, (c) $29 \mathrm{~d}$ : filled ductule surrounded by microvilli.

(D) ductule, (CM) cell membrane, (EN) endocuticle, (EP) epicuticle, (MV) microvilli, (N) nucleus, (R) secretion reservoir. (bars $=1 \mu \mathrm{m}$ ).

the larval food proteins (fig 5a-c), a hypothesis already assumed by Halberstadt (1980). During the hive bee phase, larval food protein production makes up the main proportion of newly synthesized proteins, amounting to $80 \%$ of the net synthesis (Takenaka and Kaatz, 1987). Consequently, the volume of the secretion reservoirs reflects the amount of produced and stored larval food proteins and gives rise to the changing size of the acini. For this reason as commonly practiced, the size of the hypopharyngeal glands can be used to ea- sily estimate the glandular activity and physiological status of the summer bee (Maurizio, 1954; Rutz et al, 1976). In spite of contradictory data (Brouwers, 1982), the volume of the glands is recommended for such an estimation of the physiological status of a worker honey bee. However, it must be taken into account that the abovementioned typical developmental patterns of hypopharyngeal gland activities can be influenced by colony conditions as well as by seasonal changes. Maurizio (1954, 1962b) stated that pollen supply is requi- 


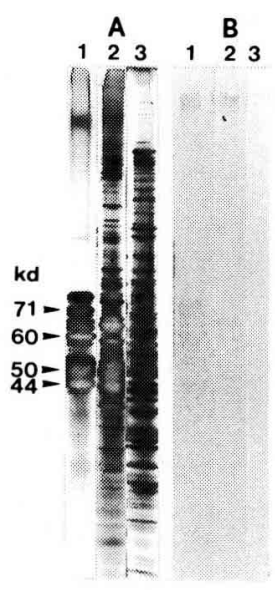

Fig 4. Detection of larval food proteins by a royal jelly-antiserum. Silver-stained electrophoretic separation (A) and immunoblot (B) of 1) hypopharyngeal gland homogenate, $6 \mathrm{~d}$ nurse bee, 2) worker jelly sampled from of 1-2 d larvae and 3) cephalic labial gland proteins, $6 \mathrm{~d}$ nurse bee. kd : Kilodalton. The antiserum recognized specifically only hypopharyngeal glandderived larval food proteins.

red for the initial growth of the glands. Furthermore, the presence of brood is essential for the maintenance of glandular size (Free, 1961) and larval food production (Huang and Otis, 1989). In caged bees, normal gland development is inhibited (Crailsheim and Stolberg, 1989). Winter bees, although with hypertrophied acini, show a low rate of protein synthesis (Brouwers, 1982).

Changes in glandular volume and rate of protein synthesis characterize the 2 distinct major functional phases of the glands during imaginal normogenesis (Halberstadt, 1980): production of larval food and honey processing enzymes. Both phases evidently overlap to some extent. This is indicated by the occurrence of small amounts of larval food protein in the secretion reservoirs of foragers as well as by the detection of newly synthesized larval food protein in foraging workers (Takenaka and Kaatz, 1987). Maurizio (1959, 1961, $1962 a, b)$ has already shown that there is a maximum of hydrolyzing sugar-inverting enzymes in old foraging bees, but that some activity is already detectable in young bees with well-developed glands, as well as in winter bees.

The simultaneous occurrence of honey processing enzymes and larval food in the hypopharyngeal gland requires their cytological compartmentalization. We have shown that larval food proteins are stored in the secretion reservoirs throughout the nurse phase. This means that the hypopharyngeal glands are not compartmentalized into different functional parts, but into different secretory compartments within ihe same gland cell, as hypothesized by Wetzig (1964), Cruz-Landim and Hadek (1969), Ortiz-Picon and Diaz-Flores (1972). However, neither the storage sites for sugar-inverting enzymes nor any selective secretory mechanism, which must necessarily exist, have been studied yet.

The partially overlapping functional phases and the persistence of the structural apparatus for production and storage of larval food protein in the hypopharyngeal glands throughout the imaginal life of the worker seem to be, respectively, functional and morphological characteristics of the flexibility within the colonial division of labour. Caste evolution (Engels, 1990) may have been guided by conflicting forces that promote ergonomic efficiency on the one hand and flexibility responding to environmental challenges on the other. The nursing capacity of the worker bee is obviously an example of a highly flexible system. Its adaptability is especially apparent in the case of colony manipulations (Rösch, 1930) in which the larval food production could, for nursing purposes, be reactivated in old foraging bees. 

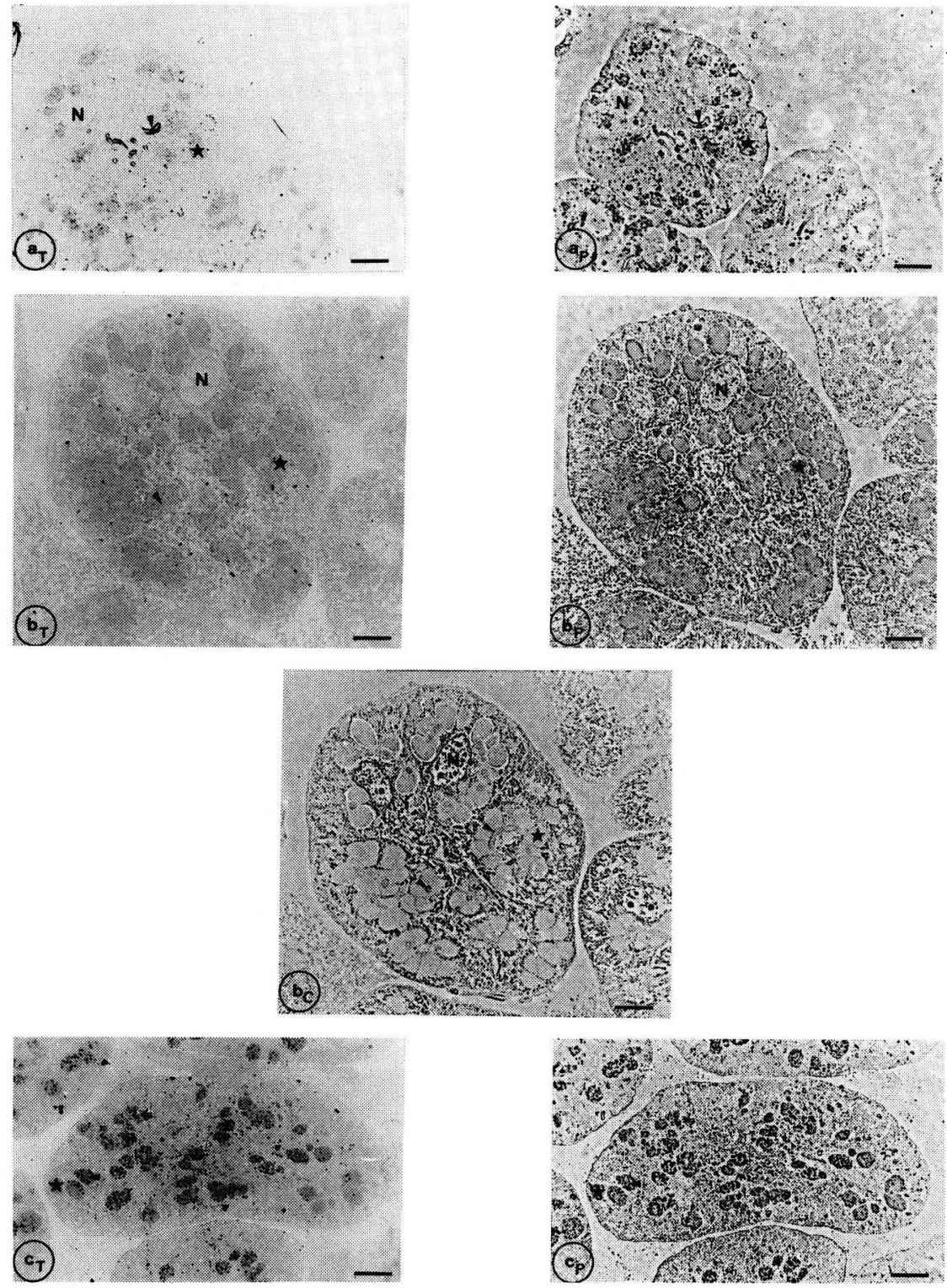

Fig 5. Immunocytochemical localization of larval food proteins in the hypopharyngeal glands. Glandular sections of $0 \mathrm{~d}$ young worker (a), $8 \mathrm{~d}$ nurse bee (b) and $29 \mathrm{~d}$ forager (c) were incubated with royal jelly-antiserum and PAP stained (peroxidase-anti-peroxidase method). Transmission (a-cT) and phase contrast $\left(a-c_{p}\right)$ light micrographs. The secretion reservoirs $(\star)$ and exporting ducts $(\rightarrow)$ of the intracellular ductules are labelled throughout the worker's entire life. $\left(b_{c}\right)$ consecutive control section of an $8 \mathrm{~d}$ worker, stained without primary antibody. (N) nucleus, (bars $=50 \mu \mathrm{m}$ ). 


\section{ACKNOWLEDGMENTS}

We are grateful to $W$ Engels for critically reading the manuscript and $\mathrm{C}$ Bardele, $\mathrm{K}$ Eisler and $\mathrm{H}$ Schoppmann for support in the electron microscopy.

Résumé - Modalités de production de la nourriture larvaire par les glandes hypopharyngiennes chez les ouvrières d'abeilles adultes. Outre les enzymes pour l'élaboration du miel, les glandes hypopharyngiennes des ouvrières produisent une part importante de la nourriture larvaire. On a étudié au niveau de l'ultrastructure, chez des ouvrières adultes de divers âges, les modifications des systèmes de synthèse et de stockage des glandes nourricières au cours du développement normal. On a ensuite déterminé in vivo l'activité de synthèse des cellules glandulaires par injection d'un traceur ( ${ }^{35} \mathrm{~S}$-méthionine) et localisé par immunocytochimie les protéines larvaires qu'elles produisent.

La quantité de reticulum endoplasmique brut dans les cellules glandulaires (fig 1) varie en fonction de l'âge. Elle augmente juste après l'émergence (fig 1a, b), atteint un maximum au stade nourrice puis diminue et reste à un niveau bas chez les butineuses (fig 1d). Ce mode de développement se reflète dans les quantités de protéines synthétisées par les glandes hypopharyngiennes (fig 2). Au cours des 4 premiers j de l'ontogenèse, la synthèse protéique augmente de plus de 20 fois. C'est à la phase nourrice que l'on observe les taux les plus élevés et ce n'est que chez les ouvrières, qui sont âgées de $20 \mathrm{j}$, que la synthèse protéique diminue fortement, de plus de $90 \%$.

Chaque glande cellulaire d'un acinus est pourvue d'un système de stockage propre et d'un canal d'évacuation (fig 3ac). La lumière du canal d'évacuation est limitée par une épicuticule fine et poreuse et une endocuticule fibrillaire. Les secrétions glandulaires sont stockées dans un réservoir qui occupe l'espace entre la membrane riche en microvillosités des cellules glandulaires et l'endocuticule. Le réservoir et le canalicule qui en sort sont séparés de la cellule glandulaire par une membrane cellulaire commune et désignés un peu à tort dans la littérature par canalicules intracellulaires. Ils forment à l'évidence une unité fonctionnelle. Les réservoirs à sécrétions subissent des modifications importantes de volume au cours du développement imaginal. Ils sont encore petits chez les ouvrières au stade nymphe (fig 3a), grossissent au cours des jours suivants pour atteindre un maximum au $8^{\theta}$ j (fig $3 b$ ). Quand les ouvrières deviennent butineuses, les réservoirs à sécrétions se rétrécissent (fig 3c). Les modifications typiques en fonction de l'âge du volume des glandes hypopharyngiennes globales au cours de l'ontogenèse sont principalement dues aux modifications de volume des réservoirs à secrétions.

Les protéines de la nourriture larvaire sont décelables dans les canalicules d'évacuation et les réservoirs à secrétions (fig 5 a-c) par immunocytochimie à l'aide d'un antisérum spécifique anti gelée royale (fig 4). Pour la première fois on a pu confirmer I'hypothèse selon laquelle les protéines de la nourriture larvaire étaient stockées dans les réservoirs à secrétions. L'intensité de la coloration immunocytochimique dépend de l'âge des ouvrières. On peut ainsi déjà reconnaître un léger marquage des réservoirs à secrétions chez les ouvrières récemment écloses (fig 5a). II augmente de façon continue jusqu'au $8^{\mathrm{e}} \mathrm{j}$ où il est maximal (fig 5b). Même chez les butineuses les protéines de la nourriture larvaire sont présentes, avec un marquage beaucoup plus faible bien sûr (fig $5 c$ ).

Manifestement, les 2 principales fonctions des glandes nourricières, production 
de nourriture larvaire et production d'enzymes, ne s'excluent pas mutuellement, mais s'exercent en partie parallèlement. La présence de nourriture larvaire jusqu'au stade butineuse contribue sans aucun doute à ce que la colonie d'abeilles puisse réagir de façon flexible à des exigences de soin au couvain et s'adapter rapidement aux conditions fluctuantes du milieu. Ceci explique aussi les anciennes observations selon lesquelles des butineuses peuvent redevenir nourrices en cas de besoin.

\section{Apis mellifera / glande hypopharyn- gienne / synthèse protéique / ultrastruc- ture / immunocytochimie / ontogenèse}

\section{Zusammenfassung - Altersabhängige Muster der Larvenfuttersaftproduktion in den Hypopharynxdrüsen adulter Ho- nigbienenarbeiterinnen. Die Hypopha- rynxdrüse der Arbeiter in produziert we- sentliche Anteile des Larvenfuttersaftes, außerdem Enzyme für die Honigbereitung. Bei imaginalen Arbeiterinnen unterschiedli- chen Alters wurde untersucht, wie sich Synthese- und Speicherapparat der Futter- saftdrüsen während der Normalentwik- klung ultrastrukturell verändern. Ferner wurde die Syntheseaktivität der Drüsenzel- len mit Tracerinjektionen in vivo bestimmt und die von ihnen produzierten Larvenfut- tersaftproteine immunocytochemisch loka- lisiert.}

Die Menge an rauhem endoplasmatischen Retikulum in den Drüsenzellen (Abb 1) verändert sich altersabhängig. So steigt der Gehalt an rauhem endoplasmatischen Retikulum nach dem Schlüpfen an (Abb $1 a, b)$, erreicht ein Maximum im Ammenalter (Abb 1c) und sinkt bei Sammlerinnen auf ein konstant niedriges Niveau ab (Abb 1d). Dieses Entwicklungsmuster spiegelt sich in der in vivo-Proteinsyntheseleistung der Hypopharynxdrüse wider (Abb 2). Im Verlauf der ersten vier Tage der Ontoge- nese steigt die Proteinsynthese um mehr als das 20fache an. In der Ammenphase können die höchsten Proteinsyntheseraten beobachtet werden. Erst bei Sammlerinnen, die älter als 20 Tage sind, vermindert sich die Proteinsynthese drastisch um mehr als $90 \%$.

Jede Drüsenzelle eines Acinus ist mit einem eigenen Speicherapparat und Ausführgang ausgestattet (Abb $3 a-c)$. Das Lumen des Ausführgangs wird von einer dünnen, porösen Epicuticula und einer fibrillären Endocuticula begrenzt. Die Drüsensekrete werden im Sekretspeicher gelagert, der den Raum zwischen der Mikrovillireichen Zellmembran der Drüsenzelle und der Endocuticula einnimmt. Sekretspeicher und ausführendes Kanälchen sind von der Drüsenzelle durch eine gemeinsame Zellmembran abgegrenzt und werden in der Literatur etwas irreführend als intrazelluläres Kanälchen bezeichnet. Offenbar bilden sie eine funktionelle Einheit. Die Sekretspeicher unterliegen im Verlauf der imaginalen Ontogenese erheblichen Volumenveränderungen. Sie sind bei pharat adulten Arbeiterinnen noch klein ( $\mathrm{Abb} 3 \mathrm{a}$ ) und vergrößern sich während der nächsten Tage der Entwicklung, bis sie ein Maximum am 8. Tag erreichen (Abb 3b). Wenn die Arbeiterinnen als Sammlerinnen tätig werden, schrumpfen ihre Sekretspeicher (Abb $3 \mathrm{c}$ ). Die typischen altersabhängigen Volumenveränderungen der gesamten Hypopharynxdrüse während der adulten Ontogenese werden offenbar in erster Linie durch die Volumenänderungen der Sekretspeicher verursacht.

Larvenfuttersaftproteine sind mit einem spezifischen Antiserum gegen Gelée Royale (Abb 4) immunocytochemisch in den ausführenden Kanälchen und den Sekretspeichern nachweisbar (Abb 5a, b). Damit konnte erstmalig die Vermutung belegt werden, daß Larvenfuttersaftproteine in den Sekretspeichern gelagert werden. 
Die Intensität der immunocytochemischen Färbung hängt vom Alter der Arbeiterin ab. So läßt sich bereits bei frisch geschlüpften Arbeiterinnen eine erste schwache Markierung in den Sekretspeichern erkennen (Abb 5a). Sie nimmt kontinuierlich zu, bis ein Maximum um den 8. Tag erreicht ist (Abb 5b). Selbst bei Flugbienen kommen Futtersaftproteine vor, allerdings ist die Nachweisreaktion deutlich schwächer (Abb 5c).

Offensichtlich schließen sich beide Hauptfunktionen der Futtersaftdrüse, Futtersaft- und Enzymproduktion, nicht gegenseitig aus, sondern werden teilweise nebeneinander ausgeübt. Das Vorhandensein von Larvenfuttersaft bis in die Flugbienenphase hinein trägt ohne Zweifel dazu bei, daß das Bienenvolk flexibel auf Pflegeerfordernisse im Brutgeschäft reagieren und sich damit wechselnden Umweltbedingungen rasch anpassen kann. Dies erklärt auch die alten Beobachtungen, daß Sammlerinnen bei entsprechendem Bedarf im Volk wieder als Ammenbienen tätig werden können.

\section{Apis mellifera / Hypopharynxdrüse / Proteinsynthese / Ultrastruktur / Immu- nocytochemie / Ontogenese}

\section{REFERENCES}

Beams HW, Tahmisian TN, Anderson E, Devine RL (1959) An electron microscope study on the pharyngeal glands of the honeybee. $J U /$. trastr Res 3, 155-170

Brouwers EVM (1982) Measurement of hypopharyngeal gland activity in the honeybee. $J$ Apic Res 21, 193-198

Crailsheim K, Stolberg E (1989) Influence of diet, age and colony condition upon intestinal proteolytic activity and size of the hypopharyngeal glands in the honey bee (Apis mellifera L). J Insect Physiol 35, 595-602
Cruz-Landim C, Hadek R (1969) Ultrastructure of Apis mellifera hypopharyngeal gland. Proc VI Congr IUSSI, Bern, 121-130

Engels W (1990) ed Social insects - an evolutionary approach to castes and reproduction. Springer-Verlag, Berlin, Heidelberg

Free JB (1961) Hypopharyngeal gland development and division of labour in honeybee (Apis mellifera L) colonies. Proc $R$ Entomol Soc Lond 36, 5-6

Halberstadt K (1970) Ein Beitrag zur Ultrastruktur und zum Funktionszyklus der Pharynxdrüse der Honigbiene (Apis mellifica L). Cytobiologie 2, 341-358

Halberstadt K (1980) Elektrophoretische Untersuchungen zur Sekretionstätigkeit der Hypopharynxdrüse der Honigbiene (Apis mellifera L). Insectes Soc 27, 61-77

Hassanein $\mathrm{MH}$ (1952) The effect of infection with Nosema apis on the pharyngeal salivary glands of the worker honey bee. Proc $R$ Entomol Soc Lond 27(a), 22-27

Huang ZY, Otis GW (1989) Factors determining hypopharyngeal gland activity of worker honey bees (Apis mellifera L). Insectes Soc 36, 264-276

Jaycox ER (1976) Behavioral changes in worker honeybees (Apis mellifera $L$ ) after injection with synthetic juvenile hormone (Hymenoptera: Apidae). J Kans Entomol Soc 49, 165-170

Kaatz HH, Hagedorn HH, Engels W (1985) Culture of honeybee organs: development of a new medium and the importance of tracheation. In Vitro Cell Dev Biol 21, 347-352

Kratky E (1931) Morphologie und Physiologie der Drüsen im Kopf und Thorax der Honigbiene (Apis mellifera L). Z Wiss Zool 139, $120-200$

Laemmli UK (1970) Cleavage of structured proteins during the assembly of the head of bacteriophage T4. Nature 227, 680-685

Maurizio A (1954) Pollenernährung und Lebensvorgänge bei der Honigbiene (Apis mellifica L). Landwirtsch Jahrb Schweiz 68, 115-182

Maurizio A (1959) Breakdown of sugars by inverting enzymes in the pharyngeal glands and midgut of the honeybee. 2. Winter bees (Carniolan and Nigra). Bee World 40, 275283 
Maurizio A (1961) Zuckerabbau unter der Einwirkung der invertierenden Fermente in Pharynxdrüsen und Mitteldarm der Honigbiene (Apis mellifera L). 3. Fermentwirkung während der Überwinterung bei Bienen der Ligustica-Rasse. Insectes Soc 8, 125-175

Maurizio A (1962a) Zuckerabbau unter der Einwirkung der invertierenden Fermente in Pharynxdrüsen und Mitteldarm der Honigbiene (Apis mellifica L) 4. Sommerbienen der italienischen, kaukasischen und griechischen Rasse. Insectes Soc 9, 39-72

Maurizio A (1962b) Zuckerabbau unter der Einwirkung der invertierenden Fermente in Pharynxdrüsem und Mitteldarm der Honigbiene (Apis mellifica L) 5. Einflu $B$ von Alter und $\mathrm{Er}$ nährung der Biene auf die Fermentaktivität der Pharynxdrüse. Ann Abeille (Paris) 5, 215-232

Ortiz-Picon JM, Diaz-Flores L (1972) Étude structurale, optique et électronique, des glandes hypopharyngiennes de Apis mellifera. Trabajos del Instituto Cajal de Investigaciones Biologicas 64, 223-240

Robinson GE (1987) Regulation of honey bee age polyethism by juvenile hormone. Behav Ecol Sociobiol 20, 329-338

Rösch GA (1930) Untersuchungen über die Arbeitsteilung im Bienenstaat, 2. Teil. $Z \mathrm{Vgl}$ Physiol 12, 1-71
Rutz W, Gerig L, Wille H, Lüscher M (1976) The function of juvenile hormone in adult worker honey bees (Apis mellifera). J Insect Physiol 22, 1485-1491

Simpson J, Riedel IBM, Wilding N (1968) Invertase in the hypopharyngeal glands of the honeybee. J Apic Res 7, 29-36

Soudek $S$ (1927) The pharyngeal glands of the honeybee. Bull Ec Sup Agron Brno RCS 10 , 1-63

Sternberger LA (1979) Immunocytochemistry. Second edition, John Wiley and Sons, New York

Takenaka T, Kaatz HH (1987) Protein synthesis by hypopharyngeal glands of worker honey bees. In: Chemistry and Biology of Social Insects (Eder J, Rembold H, eds) Peperny, München

Towbin H, Staehelin T, Gordon J (1979) Electrophoretic transfer of proteins from polyacrylamide gels onto nitrocellulose sheets. Procedure and some applications. Proc Natl Acad Sci USA 76, 4350-4354

Wetzig $H$ (1964) Histologische und histochemische Untersuchungen über die Pharynxund Hinterkopfdrüse der Honigbiene (Apis mellifica L). Acta Histochem 19, 85-96 